$4 \cdot 3$ の場合と全く同じ条件扣よび操作法で反応させた。カセイン 一ダ粒管の重量增加は $2.0 \mathrm{~g}$ トラップ中の捕捉留分は $15.5 \mathrm{~g}$ で, 気一夜クロマトグラフィーにより，アセトアルデヒド，アセトン， tーブタノール，DTBP の混合物であることを確認した。一方反応 湖はそのまま蒸留し，低沸点留分のアセトン, $t$-ブタノールはト ラップ中のるのと合一した。高沸点留分は隇圧蒸留により $75 \mathrm{~g}$ (74\%)の原料エステルを回収したあと， $\mathrm{N}^{\prime} 、 \mathrm{~V}^{\prime}$ を蒸留で単離し た (データは表 2 参照)。蒸留残渣 $14.5 \mathrm{~g}$ はベンゼンに溶かして から石油エーテルにて再沈殿精製し, 分子量 658 (ベンゼン溶液 の水点降下法による）のものを $6 \mathrm{~g}$ 得た。な拉 $\mathrm{N}^{\prime}$ の標品を次の 方法で合成し，IR で同定を行なった。

$\boldsymbol{\alpha}, \boldsymbol{\beta}$-ジアセチル-a-メチルイソパレリアン酸エチル $\left(\mathrm{IV}^{\prime}\right): 26 \mathrm{~g}$ $(0.2 \mathrm{~mol})$ のアセト酢酸エチルより， N 標品合成と同様な操作 法で $\alpha$-メチルアセト酢酸エチルを合成した。収量 $17 \mathrm{~g}(60 \%)$,
表 3 元素分析値（カッコ内は計算値）

\begin{tabular}{|c|c|c|c|}
\hline II III 2,4-D & $\begin{array}{l}\text { C } 46.32(45.57) \text {, } \\
\text { c } 58.47(58.05) \text {, }\end{array}$ & $\begin{array}{l}\text { H } 4.45(3.82) \text {, } \\
\text { H } 8.08(7.58)\end{array}$ & $\mathrm{N} 23.63(23.62)$ \\
\hline III の 2,4-D & C $46.91(46.15)$, & H $4.46(4.06)$, & N 20.73(20.51) \\
\hline N & C $60.84(61.66)$, & H $8.91(8.47)$ & \\
\hline $\begin{array}{l}\mathrm{N} \text { の 2,4-D } \\
\mathrm{V}\end{array}$ & $\begin{array}{l}\text { C } 47.29(48.08) \text {, } \\
\text { C } 60.58(60.31) \text {, }\end{array}$ & $\begin{array}{l}\text { H } 4.49(4.56) \text {, } \\
\text { H } 8.10(8.44)\end{array}$ & N 20.02(19.51) \\
\hline $\mathbf{N}^{\prime}$ & C $63.15(63.13)$, & H $9.10(8.83)$ & \\
\hline $\begin{array}{l}\mathrm{N}^{\prime} \text { の 2,4-D } \\
\mathrm{V}^{\prime}\end{array}$ & $\begin{array}{l}\text { C } 49.11(48.98) \text {, } \\
\text { C } 62.15(62.00) \text {, }\end{array}$ & $\begin{array}{l}\text { H } 4.96(4.80) \text {, } \\
\text { H } 8.87(9.10)\end{array}$ & N $18.98(19.04)$ \\
\hline
\end{tabular}

bp $91.5 \sim 92.0^{\circ} \mathrm{C} / 34 \mathrm{mmHg}$ 。つぎにこれを $4.3 \mathrm{~g}(0.03 \mathrm{~mol})$ と りそのナトリウム塩を調製してから $5 \mathrm{~g}(0.03 \mathrm{~mol})$ のアセチル イソプロピルブロミドを加え, 反応させてから蒸留により $N^{\prime}$ を $0.3 \mathrm{~g}(5 \%)$ 得た。bp $92 \sim 93^{\circ} \mathrm{C} / 2 \mathrm{mmHg}$ 。

(1964 年 10 月 19 日、第 15 回有機反応機構討論会講演)

\title{
アイソタクチックポリブテン-1 の結晶変龍と捕捉ラジカルの挙動†
}

(昭 和 40 年 1 月 16 日 受理)

楠本 直*. 福田建二**. 河野岩造**. 高柳素夫***

アイソタクチックポリブテン-1 の溶融結晶化試料 2 種 (Nattal) の結晶変態, Mod. I おょび Mod. II), 溶液結晶化 試料 (Mod. III) および急冷試料（ほほ無定形）について $-196^{\circ} \mathrm{C}$ 真空中で $\gamma$ 線を照射したのち ESR 測定を行なった。 ラジカルの反応性と分子運動との関連を調べるため, NMR および動的粘弾性の測定も同時に行なった。一 $120^{\circ} \mathrm{C}$ 以下の ESR スペクトルはすべてはやけた 6 本構造を含んでいるが, $-70^{\circ} \mathrm{C}$ 以上では 8 重項スペクトルを示す Mod. I, II のグ ループと，4重項スペクトルを示す Mod. III および無定形試料のクループに分かれる。一方， $-196^{\circ} \mathrm{C}$ から順次年温し たときのラジカル量の変化を測定すると，各温度でラジカルの比残存量は常に Mod. I >Mod. III >無定形の順であった。 ラジカルの減少は $-120^{\circ} \mathrm{C}$ 付近からゆっくり始まり, $-50^{\circ} \mathrm{C}$ から $-30^{\circ} \mathrm{C}$ 付近で急になり, 無定形試料では $-20^{\circ} \mathrm{C}$, Mod. III の試料では $-10^{\circ} \mathrm{C}$ 付近でラジカルが消减する。Mod. I の試料は $70^{\circ} \mathrm{C}$ 付近で, 8 重項を示すラジカルが消減 する。

Mod. I および無定形試料では, $-35^{\circ} \mathrm{C}$ のガラス転移温度と $-80^{\circ} \mathrm{C}$ とに非晶領域の局所的な分子運動に基つく $\mathrm{NMR}$ 吸収線幅の狭化があり,さらに $-180^{\circ} \mathrm{C}$ 以下に側鎖の運動に基つく狭化が認められた。粘弾性測定の結果にもこれらの狭 化に対応する分散領域を認めた。ガラス転移温度での分子運動はラジカルの急速な消隇を招く。一方，ガラス転移温度以 下の領域では，局所的な分子運動はラシシカルの消滅に直接関係しないと推論した。

\section{1 楮言}

アイソタクチックポリブテン-1 は, 他のいくつかのポリ $\alpha-オ$ レフィン類にも見られると同様にその側鎖の配位，あるいは分子 鎖ラセンの方向性などに基つくくと思われる三つの結晶変態)を持 っている。これらの結晶変態は, その物性を種々の面から比較検 討するときには, 一面に打いて結晶構造と分子鎖の熱運動性,さ らにいいかえれば分子間相互作用に関する知見を得るために有用 な材料となるだろう。著者らは，すでにアイソタクチックポリブ テンー1 の最も安定な結晶変態) (Modification I) と無定形物と

† 本報告を「ボリオレフィンの磁気共鳴に関する研究（第 2 報)」とする。

* Naoshi KUSUMOTO 九州大学工学部原子核工学教室 : 福 岡市箱崎町.

** Kenzi HUKUDA, Iwazo KAWANO 九州大学教養部物理 学教室: 福岡市大坪町.

*** Motowo TAKAYANAGI 九州大学工学部応用化学教室 : 福岡市箱崎町.

1) G. Natta, Makromol. Chem. 65़, 139 (1963).
について， 線照射したときに捕捉されるラジカル種が熱処理に よってそれぞれ全く異なったものに変るという ESR の観測結果 を報告した ${ }^{2)}$ 。ここではさらに溶融物を高温で結晶化して得られ る準安定な結晶変態 (Modification II)，および溶液から結晶化 して得られる結晶変態 (Modification III) について検討を加えた 結果を報告する。この際, ラジカルの反応性は分子鎖の熱運動と す密接な関係を持っていることから,ブロードライン NMR と動 的粘弾性を測定し, ラジカル挙動を分子運動性の面からる併せて 検討することにした。

\section{2 実 験 方 法}

\section{$2 \cdot 1$ 試 料}

試料（a ）扣よび (d)は (Petro-tex, Petro-tex 社製アイン タクチックポリブテン-1）からすでに報告した方法2)により作成 したもので（a）は最も安定した結晶変態（Mod. I）を含も部 分結晶化試料，(d)はほぼ無定形と見なされる急冷試料である。

2) 福田, 楠本, 河野, 高柳, 工化 67, 2163 (1963). 
試料（b ）は，適当な大きさに切断した成 形物を溶融したのち $100^{\circ} \mathrm{C} て ゙$ 放置結晶化 させたものである。融点以下での Mod. II から I への転移は室温付近が最も早 (3)が, $100^{\circ} \mathrm{C}$ で結晶化した直後は転移 速度が遅いため Mod. II のみが生じてい $ろ^{2)}$ 。(c) 試料はエーテル抽出残分の $0.5 \%$ デカリン溶液を室温に放置して結 晶化させて作成した。この結晶構造は,

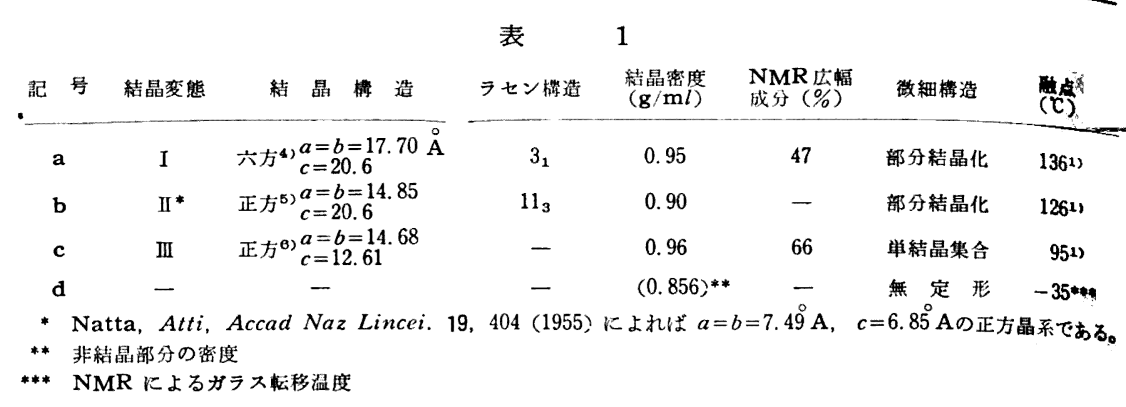

Mod. III 飞相当する。以上の試料の特性をむとめると表 1 のよう になる。

(c) 試料は制限視野電子線回折により単結晶集合体であること が確かめられた6)。

\section{$2 \cdot 2$ ESR 測定}

日立，MPU-3 型磁気共鳴分析計を用いた。本器は X-ban-1 い: $100 \mathrm{kc}$ 変調を用いている。試料は, $10^{-4} \mathrm{mmHg}$ 以下に排気した 後, 試料空胴插入部の外径が $3 \mathrm{~mm}$ の硬質ガラス管中に封入し た。試料（b）は室温では Mod. I への固相転移速度が早いため 注意が必要で，排気操作中は $100^{\circ} \mathrm{C}$ に保った。試料の排気封入 後, 液体窒素中で $\gamma$ 線照射を行なった。線源には, ${ }^{60} \mathrm{Co}$ を用い， $4 \times 10^{7} \mathrm{r} / \mathrm{hr}$ の線量率で約 $3 \times 10^{7} \mathrm{r}$ の照射を行なった。ESR 測定 には測定中試料温度を変えて，ESR スペクトルの形の変化を観 測する場合と，陚料を一定時間熱処理したときのスペクトル強度 （ラジカル濃度）の減少を測定する場合とがある。スペクトル形 の变化の測定は, 前報 ${ }^{2)}$ と同じ試料温度可変装置を用いて行なっ た。スペクトル強度は，それそれの試料を低温から順に始めて適 当な熱処理温度で 3 分間ずつ熱処理したのち常に $-196^{\circ} \mathrm{C}$ で測定 した。この場合液体窒素を満たした石英デュワーびん内には，試 料へできるだけ近い位置にテフロンの円柱内に入れた $\mathrm{Mn}^{2+} ※ 1{ }^{1}$ が 䧣準試料として置いてある。

\section{$2 \cdot 3$ ブロードライン NMR の測定}

日立 MPU-3 型磁気共鳴分析計を用いた。本器は分光器の一部, および電磁石が ESR 測定の場合と共通になっており,ブリッジ 交換等の若干の手続きによって，ESR 測定から NMR 測定に切 り換えることができる。NMR 検出はブリッジを用い，試料を入 れる線輪は液体空素あるいはドライアイスのような寒剤を使用す るクライオスタットの一端に内装されている。これにより試料温 度を $-190^{\circ} \mathrm{C}$ 付近から $+60^{\circ} \mathrm{C}$ 付近まで $\pm 1^{\circ} \mathrm{C}$ の精度で保った。

\section{$2 \cdot 4$ 動的粘弾性の測定}

動的粘弾性の測定には東洋測器社製直読式粘弾性測定器 (パイ ブロン）を用いた。周波数は $100 \mathrm{c} / \mathrm{s}$ である。

\section{3 実 験 結 果}

\section{$3 \cdot 1$ ESR スペクトルの温度変化}

図 1 は, 試料(b)の ESR スペクトルの温度変化である。 -120 ${ }^{\circ} \mathrm{C}$ 以下の低温度では，ぼやけた 6 本構造を含むと思われる図形 を示しているが, $-120^{\circ} \mathrm{C}$ 付近からやや形が変化し始める。 -70 ${ }^{\circ} \mathrm{C}$ 以上ではその変化は顕著で，温度の上昇化伴って 8 本構造が
3) J. Boor, Jr., J. Polymer. Sci. A 1, 59 (1963).
4) G. Natta, Nuoro Cimmento. 15, Suppl. 52 (1960).
5) A. Turner, J. Polymer Sci. B 1, 456 (1963).
6) 安田，高柳，未発表。
※1 $\mathrm{ZnS}: 0.0001 \mathrm{Mn}^{2+}$

支配的になり，室温ではほぼ 8 本構造のみとなる。四 2 には, 料 (c) の ESR スペクトルの温度变化を示す。 $-120^{\circ} \mathrm{C}$ 以下の 低温汇拀いては，(b)陚料と同じくぼやけた 6 本構造を示してい るが，その温度以下からやや图形に変化が現われ， $-70^{\circ} \mathrm{C}$ 以士 ではこれが著しくなる。しかしながら，(b)試料については8本 構造が現われたのに対し，(c)試料では 4 本構造となる。この 4

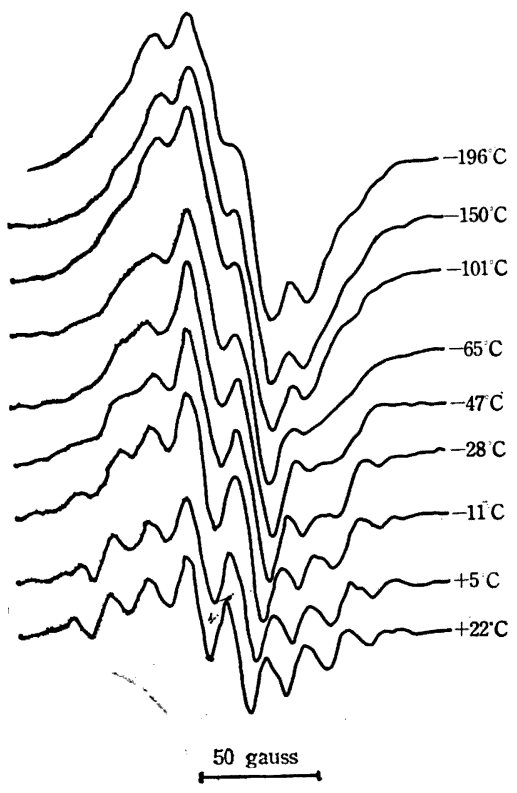

図 1 ESR スペクトルの温度変化 (b) 試料

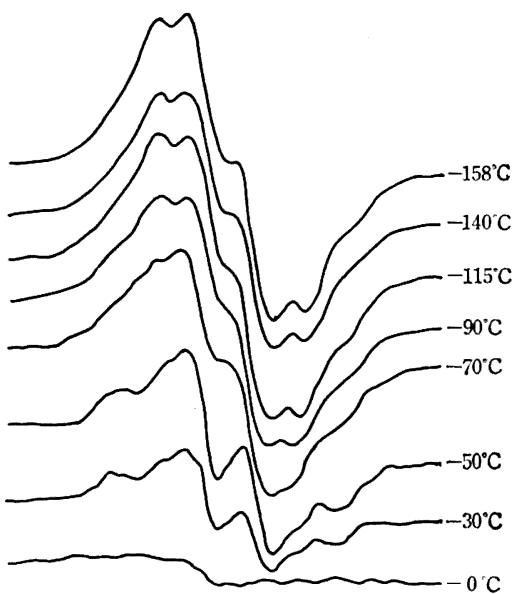

50 gauss

闵 2 ESR スペクトルの温度変化 (c) 試料 
木槽造はそのままの形を保って温度の上昇とともに減衰し， $0^{\circ} \mathrm{C}$ 付近で消隇する。

3.2 ESR スペクトル強度の熱処理による変化

困3には（a)，(c) および (d) 試料についての ESR スペク トル強度の温度変化を示す。いずれの試料にすそれぞれ特徽のあ る伐衰領域が認められるが，全温度域を通じて最も減衰が早いの は (d) 試料, 次いで, (c), (a ) の順である。低温においては, いずれの試料にも $-120^{\circ} \mathrm{C}$ 付近よりスペクトル強度のゆるやかな 衰が始まって扣り，(d)陚料では $-50^{\circ} \mathrm{C}$ 付近から更に急激な

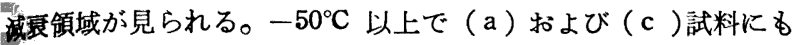
同様に急速な减衰領域が見られるが，これに至る前に中間的な領 㳦か，(a)試料に和いては $-50^{\circ} \mathrm{C}$ から $-20^{\circ} \mathrm{C}$ 付近に, (c) 試 料持いては $-60^{\circ} \mathrm{C}$ から $-30^{\circ} \mathrm{C}$ 付近に認められる。(a)試料 にはさらに $70^{\circ} \mathrm{C}$ 付近に減衰領域が認められる。

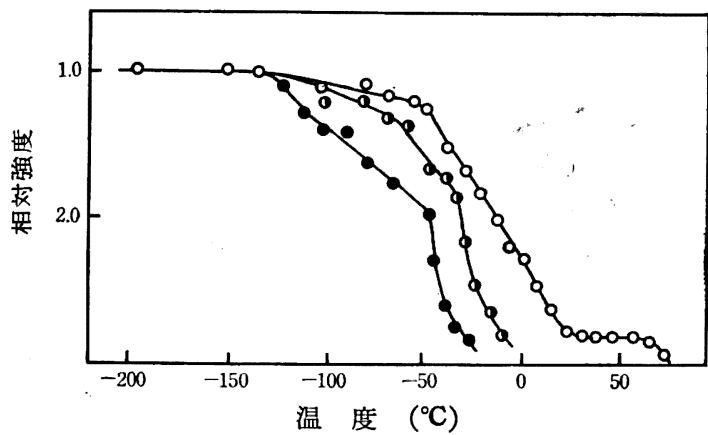

図 3 ESR スペクトル強度の熱処理による変化 O:（a) 武料, O : (c) 試料, ○:(d) 武料

\subsection{NMR 線幅の変化}

目 4 K NMR 線幅の温度変化を示す。いずれの試料にも-180 ${ }^{\circ} \mathrm{C}$ 以下で大きな線幅の狭化が起こっているのが見られるが，(c) 武料は他の二つよりるその程度が小さい。また（a ）および（b) 陚料には $-80^{\circ} \mathrm{C}$ 付近より始まる小さな狭化が見られるが，その 程度は (a) 試料よりも (d) 試料に打いて著しい。さらに $-35^{\circ} \mathrm{C}$ 付近より，（a ）および (d) 試料には大きな狭化が始まっている が，(c)試料にはこれが見られず，より高温の $-10^{\circ} \mathrm{C}$ 付近から 化が起こっている。全体的に比較すると（d）試料の線幅の変 化は（a）試料のそれとほぼ同じであるが，低温側に変化が移行 しているのに対し，（c)試料では低温より高温に至るまで線幅は 仏くまた変化が小さい。

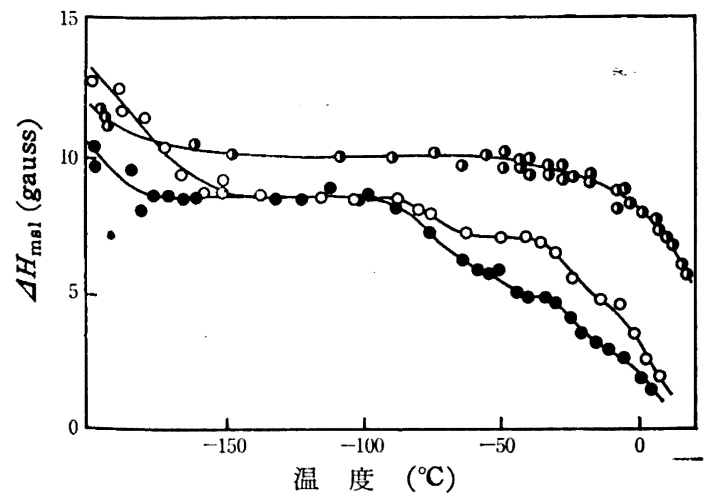

因 4 NMR 線幅の変化 $\bigcirc:$ :(a) 武料, $\bigcirc:$ :(c) 试料, ○: (d) 試料

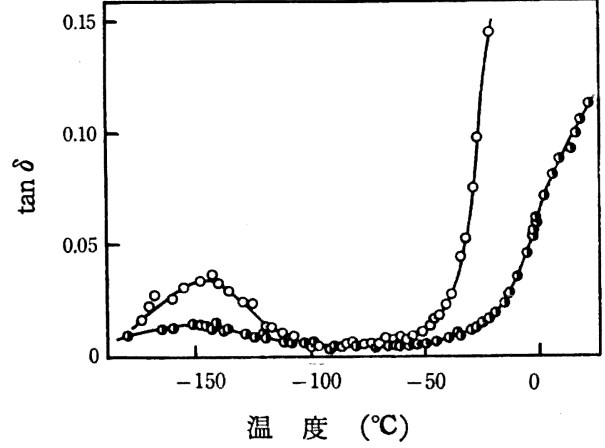

図 5 動的損失の温度变化

$O:$ :(a) 試料, $\quad$ : (c) 試料

\section{$3 \cdot 4$ 動的損失}

図 5 に (a) 抢よび (c) 試料についての動的損失の温度变化を 示す。（a ) 試料に招いて $0^{\circ} \mathrm{C}$ 付近に見られる大きな分散の損失 の山は（c）試料に見られないが，さらに特徎的なことは -150 ${ }^{\circ} \mathrm{C}$ 付近に見られる損失の山もまた（a）陚料より小さいことであ る。また両者を比較することによって $-60^{\circ} \mathrm{C}$ 付近にる極めて小 さい分散が見出される。

\section{4 考察}

4・1 試料の結晶構造と ESRスペクトルの超微細構造 (hyperfine structure, hfs)

試料（b）执よび（c）の $-120^{\circ} \mathrm{C}$ 以下の低温に打ける ESR スペクトルはいずれるぼやけた 6 本構造を含むが，これを（a） 扣よび（d）試料のスペクトルと比較すると，各試料間には線幅 の拡がりに若干の差異があるすののほとんど同じ図形であること がわかる。比較のため $-155^{\circ} \mathrm{C}$ 付近のスペクトルを図 6 に示す。 これは Loy ${ }^{7}$ の Mod. I についての測定結果とも一致してい る。更に温度を上げた場合，すでに著者らが報告2)したように，

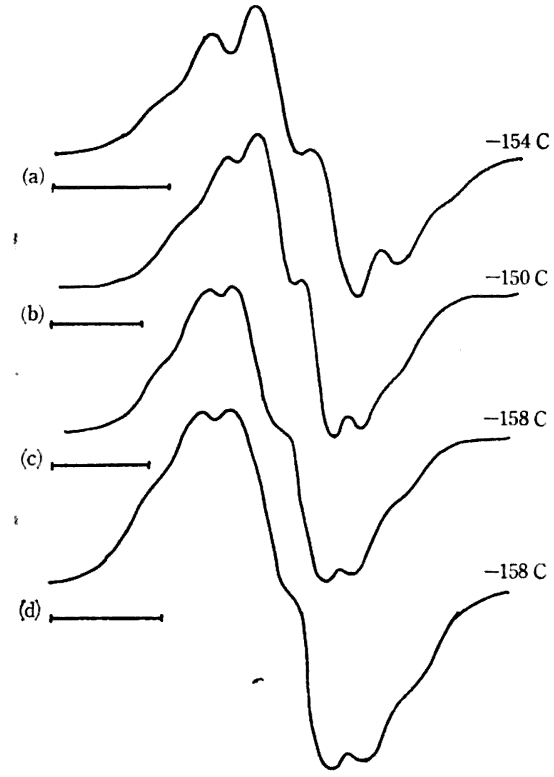

図6 - $155^{\circ} \mathrm{C}$ 付近に怙ける ESR スベクトル — はそれぞれ 50 gauss

7) B. R., Loy, J. Polymer Sci. A 1, 2251 (1961). 


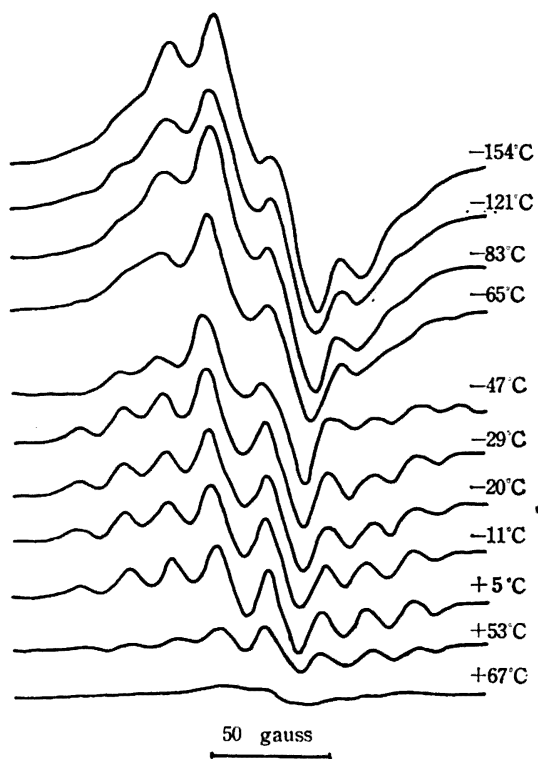

図 7 ESR スペクトルの温度変化（a）試料

(a) 試料には $-70^{\circ} \mathrm{C}$ 付近から結晶領域中に 8 重項スペクトルが 出現する。その過程を比較のため図 7 に示すが, 図 1 と比較して, スペクトルの温度変化の模様は（a）試料のそれとほとんど変ら ないことがわかる。8本構造スペクトルは（a ）試料の場合と同 じく結晶領域中に含まれていることは明らかであるが，その hfs 分離幅も約 24 gauss で等しい。ただ，（b）試料からのスペクト ルにはわずかに複雑な構造が含まれている。眓2 亿示した（c） 試料のスペクトルの温度変化が，すでに報告2) した（d）陚料の スペクトルと似ていることはさらに興味ある事実である。比較の ためこれを図 8 に示す。やはり（a）試料に対する（b）試料の スペクトルの場合と同様，(c)試料にはやや微細な構造を含むが (d)試料と分離幅す等しく非常に似通っている。ただラジカルの 消失温度は $(\mathrm{d})$ 試料の $-10^{\circ} \mathrm{C}$ よりやや高い $0^{\circ} \mathrm{C}$ 付近で起こっ ている。このような,アイソタクチックポリブテン-1 についての ESR スペクトル温度変化の特質をとりまとめてみると， $-120^{\circ} \mathrm{C}$ 以下の低温ではほとんど結晶構造による差異がないが $-70^{\circ} \mathrm{C}$ 以 上では相違が明らかになり，熱力学的に最も安定な Mod. I にお いて典型的に見られる 8 重項スペクトル型と，無定形領域に典型 的に見られる 4 重項スペクトル型に分けることができよう。比較

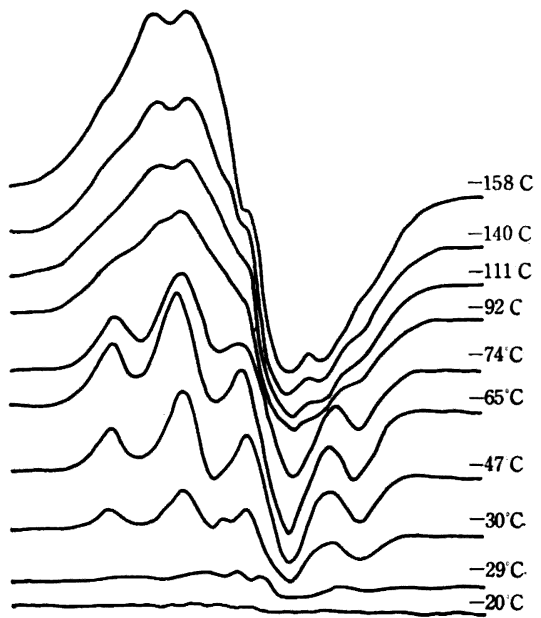

因8 ESR スペクトルの温度変化 (d) 試料 (a)<smiles>CCCCCCCCCCCCCCCCC</smiles>

(b)<smiles>C#CCCCCCCCCCCCCCCCCCCCCCCCC</smiles>

(c)

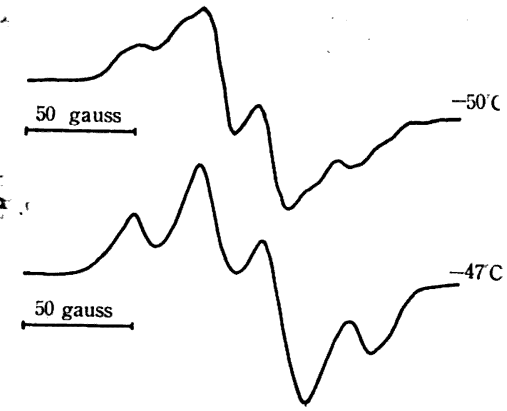

因 9 各結晶变態に特徴的な ESR スペクトル のため, 四 9 に各結晶変態に特徵的なスペクトルを示す。先述の

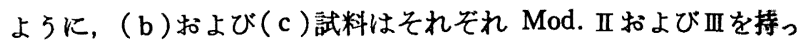
ているが, 表 1 からわかるようにその結晶密度に大きな差はなく, 無定形部分の密度とはかけ離れている。従って，単純に分子鎖の 充てん率とそれに伴 5分子鎖熱振動の相違にスペクトルの差を説 明する因子を求めることはできない。しかしながら，Mod．III が 比較的希薄な溶液からの結晶化によってでさると，また Mod. IIIが I およびII より熱力学的に不安定であることは，その融点が 95두゙他のいずれよりる低いことから明らかであるにるかかわ らず，Mod．II に見られるような固相転移が起こらないことから， （c）試料には（a)，（b ）試料に共通なラジカルの反応性を支管 する分子鎖の運動性に関する特性の一部が欠けているとも考えら れる。Mod．Ｉ，II はともに分子鎖ラセンが左右の混合であるの に対し，Mod. III はいずれか一方のみであるとする見方は一つの 示唆6)を与えるすのであろう。しかしながら，Mod. III と無定形 領域とに同じスペクトルが現われるという現象を支配する共通因 子を捜すことはなかなか困難である。

\section{$4 \cdot 2$ ラジカルの反応性と分子運動}

図 3 に示したスペクトル強度の温度変化は, 固体中に捕捉され たラジカルの反応性を示するので，曲線の勾配が大きく変る温度 領域では，ラジカルが急速に反応消隇することを示している。 た，各試料の曲線がそれぞれ異なっていることは微細構造との関 連に拈いて興味がある。一般に，高分子固体中に捕捉されたラシ カルの反応性は, ラジカルの種類とそれを保有する分子鎖の熱運 動性と密接な関係があり, 特に分子鎖のミクロブラウン運動が始 まるガラス転移あるいは溶融温度ではラジカルが急速に消隇する 例が知られている ${ }^{8,9,10,11)}$ 。これは分子運動によりラジカル同志 が出会ら頻度が增すためと考えられており，著者らの実験におけ る (d) 試料の場合, $-40^{\circ} \mathrm{C}$ 付近でのラジカルの急速な消隇は, 後述する NMR あるいは粘弾性測定の例に見られるガラス温度よ りやや低い温度で起こっているが，一応上述の現象に相当するす

8) H. Kashiwabara, Rept. Prog. Polym. Phys. Japan 5, 283 (1962).

9) N. Tamura, K. Shinohara, Rept. Prog. Polym. Phys. Japan 7, 347 (1964). 
のと考えてよいであろ 万。ポリブテン-1 は低温では 6 重項スペ クトルと 4 重項スペクトルが重なっていると考えられ2), ここで 先き火消隇するのは 6 重項スペクトルである。また（a）試料に る同じ温度領域に同様な現象を認めることができるが，勾配がゆ るやかになっているのは, 結晶領域中のラジカルによるスペクト ルが重なっているためであろう。（a）試料についてはさらに+20 ○位までラジカルの堿少が続いているが, この温度領域では結 晶領域中でのラジカル種の変化（4 重項から８重項への）扣よび 消失反応が続いているすのと考えられる。さらに高温 $70^{\circ} \mathrm{C}$ 付近 でのジカル減衰領域は 8 重項スクペトルの消滅に相当してい る。（c）試料は表 1 亿記載した NMR 広幅成分の強度から見る と，(a)試料より結晶領域がかなり大きいと考えられるが，先述 のように非晶性試料（d）と同様なスペクトルを示し，またその 領城でのラジカル堿衰の模様る曲線全体が高温側にずれただけの 形で (d) 試料とよく似ている。最後に, $-120^{\circ} \mathrm{C}$ 付近から各試 料に始をるゆるやかなラジカルの減衰は，低温で NMR あるいは 粘弹性に見られるような分子運動と直接関係つけられるであろう か。その結論を述べる前に NMR および粘弾性の测定結果につい て考察しょ5。図 10 の NMR 線幅の温度変化を低温側から見て いくと， $-180^{\circ} \mathrm{C}$ 以下で全ての試料に大きな線幅の狭化が見出さ れるが，これは側鎖の運動に対応するすのとされている(2)。ここ で注意すべきことは，無定形試料（d）が 3 種の試料のうち最も 低い温度で狭化を起こしていることで，(a)試料の狭化がこれよ り高温側にずれているのは，結晶領域の影響と考えられる。また (c)試料は狭化の程度が他の二つに比較して小さい。次に， -80 ○C 付近から（a）拈よび (d) 試料に比較的小さな狭化が見出さ れるが，その程度は（a) 試料に比へて (d) 試料の方がかなり大 きいことから，非晶領域中の主鎖の局所的な動きを反映するるの であると考えられる。結晶性のよい（c）試料にはほとんどこの 化が見られないこともその裏付けとなる。さらに $-35^{\circ} \mathrm{C}$ 以上 での狭化はガラス転移に相当するるのである ${ }^{12)}$ が（a）㧊よび (d)試料に比較して (c) 陚料はより高温で狭化が起こっている。 これはあるいは結晶内部での側鎖の運動によるすのかる知れな い。(a)，(c) および (d)の 3 者を比較すると（c）陚料が， ほ ほ結晶領域の事情を語っているのに対し，(d)試料が無定形のそ れを，そして（a）試料が，（c），(d) 両者の中間的性格を示し ていることがよくわかる。図 10 には， BPP ${ }^{13)}$ の理論を適用し て, これら分子運動について見かけの活性化エネルギーを求めた 侮の transition map を示す。図中, 側鎖の運動に関するるのを $r$, 非晶領域の局所的な運動に関するすのを $\beta$ とする。活性化エ ネルギーは側鎖の運動について $2.1 \mathrm{kcal} / \mathrm{mol}$, 非晶領域の局所的 な運動について $5.0 \mathrm{kcal} / \mathrm{mol}$ と求められた。この值はしかし計 算方法が単一緩和を仮定していることと测定にかかる対象の緩和 時間が短いため，力学あるいは誘電緩和の值の数分の一程度小さ いことを考虑して括く必要がある。次に，図 5 の粘弾性の測定結 米を見ると $-145^{\circ} \mathrm{C}$ 付近に損失の山があるが，これは側鎖の運動

10) E. T. Lowton, J. S. Balwit, R. S. Powell, J. Chem. Phys. 33, 395 (1960).

11) H. Kashiwabara, J. Phys. Soc. Japan 16, 2494 (1961).

12) A. E. Woodward, A. Odajima, R. A. Wall, J. Chem. Phys. 65, 1384 (1961).

13) N. Bleombergen, E. M. Purcell, P. V. Pound, Phys. Rev. 73, 679 (1948).

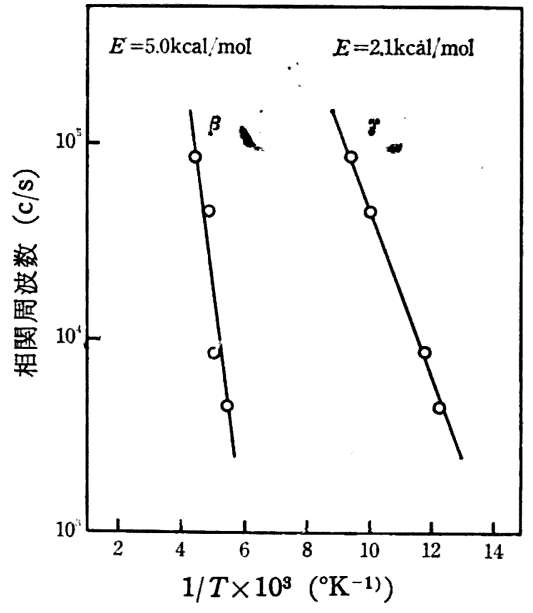

図 10 ポリブテン-1 の Transition map

によるすのとされている(4)。この温度は NMR の場合より高い が，相関周波数を考えると同一緩和過程では NMR が $10^{4} \mathrm{c} / \mathrm{s}$ の オーダーであるから $100 \mathrm{c} / \mathrm{s}$ の粘弾性の分散は NMR より低温に 移行すべきである。しかしながらその関係が逆転して観測されて いるのは NMR の測定が緩和時間の短い部分を観ているためだと 解釈される。この側鎖の運動による損失の山は (a)試料より (c) 試料が小さく NMR の線幅の狭化が小さいという結果と対応して いる。さらに $-60^{\circ} \mathrm{C}$ 付近には（a) 拈よび (c) 試料をよく比較 すると（a）試料に小さな損失の山が見出されるが，これがNMR の場合の $-80^{\circ} \mathrm{C}$ 付近の狭化に対応するすのと思われる。ここて 先の $-120^{\circ} \mathrm{C}$ 付近から始まるラジカル反応との結びつきの問題に 戻ると, 先ず, $-70^{\circ} \mathrm{C}$ 付近の非晶領域中の局所的な動き， $\beta$ 分 散とは直接関係がないよ5に見える。その理由は， $\beta$ 分散の温度 域とラジカルの減衰温度域とは余りにす違いすぎていることと, 乃分散が非晶領域に限られて括り（c）試料にはほとんど認めら れないのに, ラジカルの減衰は（c）試料に打いても（a）試料よ り多く起こっていることである。次に， $-140^{\circ} \mathrm{C}$ 以下に見出され る側鎖の動き， $\gamma$ 分散の場合を考えてみる。粘弾性の $-145^{\circ} \mathrm{C}$ の 分散は，側鎖メチル基のみの回転とは異なって主鎖にも影響を及 ぼしていると考えられるし，また（c）試料にも分散が認められ ることから主鎖にある2゙ ラジカルの反応性と関連がないとはいい 切れない。しかし関連性を示す積極的な証明がないことと， $r$ 分 散は（c）試料の方が（a 陚料より小さいにもかかわらず反応の 程度は（c）試料の方が大きいこと，扣よび温度範囲が $\gamma$ 分散は 低温側に寄り過ぎていることなどから，r分散との関連性も否定 した方がよいよ5に思われる。以上，ポリブテン-1 のガラス温 度以下の低温に打ける局所的な分子運動はラジカル反応の支配的 因子にはなりにくい，いいかえれば分子鎖構成単位の払散を伴了 融解あるいはその前駆現象，またはガラス転移のよ5に大きな分 子運動が起こる場合と異なった他の反応機構があるのではないか と考える。

(第 19 回物理学会年次大会発表)

本研究は昭和 37 年度文部省機関研究の一部であり, 文部省当 局に深く感謝する。

14) A.E. Woodward, T. A. Sauer, R. A. Wall, J. Polymer Sci. 50, 117 (1961). 